\title{
Saliva secretion difference before and after rinsing with baking soda on menopause women
}

\author{
Dewi Anggraeni, Sri Tjahajawati, Rosy Wihardja \\ Department of Oral Biology Faculty of Dentistry, University Padjadjaran
}

\begin{abstract}
Menopause women can experience decrease in saliva secretion (decrease). To understand the clear picture about saliva secretion, the volume, flow rate, $\mathrm{pH}$ and viscosity were then measured. The aim of this research was to obtain a picture about the difference of saliva secretion before and after rinsing with baking soda on menopause women. The type of the research used was a laboratory quasi experiment with comparative descriptive form. The technique used in this research is the survey method, and samples were taken using the multistage cluster random sampling method, and t-student statistical analysis. This research was conducted with the saliva collected with spitting method on 45 menopause women. The results show that the average volume, flow rate, $\mathrm{pH}$ and viscosity before rinsing with baking soda was 1.79 $\mathrm{ml}, 0.18 \mathrm{ml} /$ minute, 7.40 and $0.81 \mathrm{~mm}^{2} /$ second. The average volume, flow rate, $\mathrm{pH}$ and viscosity after rinsing with baking soda were $2.66 \mathrm{ml} ; 0.27 \mathrm{ml} /$ minute; 8.67 and $0.78 \mathrm{~mm}^{2} / \mathrm{second}$. Statistical analysis tstudent on $\mathrm{a}=0.05$ shows volume changes, flow rate, $\mathrm{pH}$ and saliva viscosity before and after rinsing with baking soda was $0.873 ; 0.086 ; 1.273$ and 0.037 respectively. The conclusion shows a significant difference between saliva secretion before and after rinsing with baking soda, and saliva secretion after rinsing with baking soda on menopause women.
\end{abstract}

Key words: saliva secretion, menopause, baking soda solution

\section{INTRODUCTION}

Saliva in oral cavity is a protection factor. It is performed by wetting and coating the teeth surface and oral mucosa, while maintaining the oral's buffer capacity. This is influenced by the saliva secretion flow rate, volume, and $\mathrm{pHs}$. If the flow rate on saliva secretion increases, then the volume will also increase, with the increase on the $\mathrm{pH}$, so the protective function inside the oral cavity will increase. ${ }^{1}$ According to Amerongen, saliva has inorganic and organic components with antibacterial influence. Inorganic components on saliva include ionic electrolytes; one is bicarbonate which is the most important buffer ion in saliva, while the organic components mainly consist of protein.

The decrease in saliva secretion decrease which can be induced by hormonal changes can occur to menopause women, because generally the hormone system has a connection with various body metabolism function, regulate the chemical reaction and substance transportation through cell membrane, and other metabolism aspects such as growth and secretion. The endocrine system change on menopause women happened because of the progressive lost of ovarian function. ${ }^{2}$ Menopause is the time when pre menopause ended and post 
menopause begins. At pre-menopause, the ovarian activity will decrease until it comes to a full stop. This condition causes the production of estrogen and progesterone hormones also decrease until non-reproducing. The result is the disturbance in the homeostasis system and the regulation of the body fluid. Estrogen and progesterone will increase the retention on sodium and the stimulation of rennin-angiotensin-aldosterone. This situation will bring positive impact on the body fluid regulation. Body fluid regulation will determine the plasma volume, and the plasma volume is equal with the salivary flow rates. ${ }^{3}$

The vasomotor complaints which consist of hot flushes, often occurring to menopause women with headache signs, sweating and depression, also with dry mouth complaints, burning sensation on the tongue and on the buccal surface of the mouth, and also the lost of salty, spicy, and sour taste to tasteless. The gingival mucosa becomes atrophic and this disorder also marked by redness, edema, dryness, the burning sensation and hypersensitivity towards stimulation. ${ }^{4,10}$ Caries on teeth surfaces and mucosa inflammation and corners of the mouth will also increase. The taste substances which stimulate secretion and parasympathicomimetica can reduce $^{5}$ the serostomic complaints, e.g. by using saliva substitution or by using the substance that stimulate saliva production, which usually has an acidic nature. But acid can decrease the saliva $\mathrm{pH}$, while in serostomic patients $\mathrm{pH}$ decrease is not expected because the complaints can be exacerbated. One of the ingredients that can stimulate salivary flow that has an alkali nature for xerostomic therapy bicarbonate inside, which is baking soda. ${ }^{6}$ Some of the advantages by using baking soda is the buffering capacity, the nature of low abrasive on high concentration, soluble in water and affordable. ${ }^{7}$ This substance can induce saliva production and helps if the salivary gland condition is still active.

The decrease on salivary flow has an effect towards the salivary buffer system inside the oral cavity, because the $\mathrm{pH}$ and salivary buffer capacity will increase along with the increase of salivary flow rate. ${ }^{5}$ The buffer system and saliva $\mathrm{pH}$ are mainly influenced by bicarbonate. Baking soda is a white fine crystal and odorless, its nature is alkali so it can neutralize acid. The alkali nature will increase in water. When reacting with water, baking soda solution will release carbon dioxide and water, so when it's rinsed inside the mouth can it increase water level. Baking soda is useful as an antibacterial agent and acid neutralizer produced by bacterial metabolism. Baking soda can also be used in toothpaste or rinsing ingredient for hyposalivation cases. ${ }^{8}$ The taste of baking soda solution will stimulate the parasympathetic nerves from nucleus salivatory superior and inferior on the brain stem. The nucleus will be excitated with tactile stimulation and tasting from the tongue and the areas of oral cavity and pharynx, thus increasing the saliva secretion. ${ }^{6,8}$

The change in acid-alkali balance will stimulate the ion change mechanism. Cations such as potassium and sodium can change hydrogen ion contained in body extracellular fluid such as in saliva. When the hydrogen ion in extracellular increases, as in acidosis or high acid level, the $\mathrm{pH}$ decreases the redistribution of potassium ions from intracellular fluid to extracellular fluid. The use of baking soda in the decreased $\mathrm{pH}$ state can bring back potassium ions inside the patient's cell with acidosis and thus normalize the $\mathrm{pHs}^{6}$. The sodium and bicarbonate concentration will increase according to the secretion rate. This will have an influence on the increase of secretion rate, bicarbonate concentration and the increase of $\mathrm{pHs}^{5}$

Baking soda is soluble in water in room temperature (around $20^{\circ} \mathrm{C}$ ). Baking soda is not soluble in alcohol. From the safety of use, baking soda is diluted in water. Baking soda is stable on open air and room temperature, so it can be stored directly in close container, and no special treatment is needed. ${ }^{6}$ This rinsing ingredient can be made independently by mixing $1 / 2$ teaspoon of baking soda and $8 \mathrm{oz}$. ( $250 \mathrm{ml}$ ) water. ${ }^{12}$

Baking soda solution in small dose and isotonic solution is relatively safe. The sideeffect of baking soda solution especially happens in connection with the usage of high-dose and concentration. The toxicity of concentrated baking soda solution in high-dose on facial tissue and mucosa will cause a local corrosive wound, which can cause necrosis and scar wound with keloid. The tissue will not form a plug for the wound because the protein coagulation will not function, thus the base can attack the deeper skin layer/mucosa. The mouth mucosa will have white 
swelling and painful. The local corrosive wounds can be handled immediately with rinsing in water for as long as 15-20 minutes. ${ }^{15}$

Generally the baking soda solution is a contraindication for patients with alkalosis respiratory or metabolic, patients with hypocalcaemia when alkalosis can cause tetanus, patients with the hyper loss of chloride cause by continuous vomiting or Gl suctioning, and also in patients with dieresis risk, which caused hypochloremic alkalosis. ${ }^{6}$

The aim of this research is to obtain data about the difference in saliva volume, the saliva flow rate, salivary $\mathrm{pH}$ and the saliva viscosity before and after rinsing with baking soda solution on menopause women in Kecamatan Jatinangor Kabupaten Sumedang.

The benefit of this research is to obtain an alternative rinsing solution which is accessible, economical, practical and safe to use for those experienced saliva decrease.

\section{MATERIALS AND METHODS}

The method used in this experiment is the Quasi Experiment, which has the purpose of making the differentiation before and after rinsing with baking soda solution on menopause women. Samples were picked using the multistage cluster random sampling method, and samples are in the form of individual group. The data was then analyzed using the coupled data test with $\mathrm{t}$ student, confidence limit $\alpha=0.05$.

The research population was menopause women with the age of 50-59 years in Kecamatan Jatinangor Kabupaten Sumedang. The samples were obtained by using the multistage cluster random sampling method. The first step was to divide the populations into clusters. Kecamatan Jatinangor consists of 12 villages, from the 12 village then the 2 village, Desa Cikeruh and Desa Cipacing was selected. The sampling consists of 45 people from the two selected villages. The number of 30 samples represents the minimum amount of samples for this survey technique. ${ }^{11}$ The inclusion subject criteria in this research are the group of menopause women (50-59 years); has ceased menstruating for at least 1 year; does not receive antibiotic, antidepressants, antihistamine, ant hypertension and diet pill treatment; has good general health, which includes no systemic disease according to the anamneses on subjects; not undergoing a current radiation therapy; not using prosthesis; not smoking; willing to participate in the research.

The tools in this research includes mouth mirror, explorer, tweezers, rinsing glass, measurement glass, beaker glass, stop watch or wrist watch, glass funnel, pipette, $\mathrm{pH}$ meter or $\mathrm{pH}$ indicator Hanna 14, tissue, viscometer (Ostwald viscousimeter 509.03 type), thermostat, tube clamp, Informed Consent. The materials used in this research are aquadest as a washing media for the food remains in the oral cavity, baking soda solution with $1 / 2$ teaspoon ( 2.5 gram) baking soda and $250 \mathrm{ml}$ aquadest, saliva as the material of research.

On pre-research the signing of informed consent, questionnaire filling, anamneses and the examination of periodontal health was conducted. The next preparation step was to prepare the baking soda solution by measuring $250 \mathrm{ml}$ of aquadest, and then put them inside the beaker glass. The $1 / 2$ teaspoon ( 2.5 gram) baking soda powder was then weighed using the analytical scale then mixed with aquadest.

The procedures of saliva extraction before rinsing with baking soda were as follows. The subject was instructed to rinsing with aquadest to clean up the food excess inside the mouth. The saliva collection was conducted with straight head position and the head tilted forward at a $45^{\circ}$ angle. ${ }^{13}$

The time of research was 12.00-15.00 WIB (local time) because in this position and time, the rate of saliva flow has reached its highest level. ${ }^{14}$ The subject kept their lips closed and let the saliva gather inside the oral cavity without swallowing or suckling for as long as 10 minutes. Every 5 minutes the gathered saliva was then spit over by bending the head downwards and the collected saliva was gathered inside the measurement glass with the aid of glass funnel. The gathered saliva was then measured by milliliter. $\mathrm{pH}$ was determined by using the $\mathrm{pH}$ meter. Viscosity was determined by using the viscometer.

The procedures of saliva extraction after rinsing with baking soda solution are as follows. The subjects were instructed to rinsing with $20 \mathrm{ml}$ baking soda solution for 30 seconds. 
Saliva secretion difference before and after rinsing with baking soda on menopause women (Dewi Anggraeni, et.al.)

Table 1. $t$-Test result on saliva volume difference before and after rinsing with baking soda solution on menopause women

\begin{tabular}{lccccc}
\hline \multicolumn{1}{c}{ Variable } & Average $\pm \mathrm{sd}$ & Average Interval $(\bar{B})$ & $\mathrm{t}$ count & $\mathrm{t}$ table & Note \\
\hline $\begin{array}{l}\text { Saliva volume }(\mathrm{ml}) \\
\begin{array}{l}\text { (Before) } \\
\text { Saliva volume }(\mathrm{ml})\end{array}\end{array}$ & $1,79 \pm 0,902$ & $-0,873$ & $-2,817$ & $-2,02$ & Difference \\
(After Baking soda) & $2,66 \pm 2,056$ & & & \\
\hline
\end{tabular}

Table 2. $\mathrm{t}$-Test results on saliva flow difference before and after rinsing with baking soda solution on menopause women

\begin{tabular}{lccccc}
\hline \multicolumn{1}{c}{ Variable } & Average $\pm \mathrm{sd}$ & Average Interval $(\bar{B})$ & $\mathrm{t}$ count & $\mathrm{t}$ table & Note \\
\hline $\begin{array}{l}\text { Saliva volume }(\mathrm{ml}) \\
\text { (Before) }\end{array}$ & $0.18 \pm 0,089$ & $-0,086$ & $-2,856$ & $-2,02$ & Difference \\
$\begin{array}{l}\text { Saliva volume }(\mathrm{ml}) \\
\text { (After Baking soda) }\end{array}$ & $0.27 \pm 0.206$ & & & \\
\hline
\end{tabular}

Table 3. $\mathrm{t}$-test results on saliva $\mathrm{pH}$ difference before and after rinsing with baking soda solution on menopause women

\begin{tabular}{lccccc}
\hline \multicolumn{1}{c}{ Variable } & Average $\pm \mathrm{sd}$ & Average Interval $(\bar{B})$ & $\mathrm{t}$ count & $\mathrm{t}$ table & Note \\
\hline $\begin{array}{l}\text { Saliva volume }(\mathrm{ml}) \\
\begin{array}{l}\text { (Before) } \\
\text { Saliva volume }(\mathrm{ml})\end{array}\end{array}$ & $7.40 \pm 0,883$ & -1.273 & -17.380 & $-2,02$ & Difference \\
$($ After Baking soda) & $8.67 \pm 0.931$ & & & \\
\hline
\end{tabular}

Table 4. Coupled t-test results on saliva viscosity before and after rinsing with baking soda solution on menopause women

\begin{tabular}{lccccc}
\hline \multicolumn{1}{c}{ Variable } & Average $\pm \mathrm{sd}$ & Average Interval $(\bar{B})$ & $\mathrm{t}$ count & $\mathrm{t}$ table & Note \\
\hline $\begin{array}{l}\text { Saliva volume }(\mathrm{ml}) \\
\text { (Before) }\end{array}$ & $0.813 \pm 0,10$ & & & \\
$\begin{array}{l}\text { Saliva volume }(\mathrm{ml}) \\
\text { (After Baking soda) }\end{array}$ & $0.777 \pm 0.11$ & 0.037 & 2.717 & 2,02 & Difference \\
\hline
\end{tabular}

Rinsing with the rinsing ingredient was recommended for around 30 seconds. ${ }^{7,12}$ The next step is the save as described above.

\section{RESULT AND DISCUSSION}

The data obtained on the volume, flow rate, saliva $\mathrm{pH}$ and its viscosity difference before and after rinsing with baking soda solution on menopause women is shown on the following table.

After rinsing with baking soda solution there was an increase in salivary volume (in $\mathrm{ml}$ ) on menopause women by $0.873 \mathrm{ml}$. According to the t-student the zero hypothesis was rejected, which means there was a difference on saliva volume before and after rinsing with baking soda solution. The increase of salivary volume had a connection with increases on the saliva flow rate. When bicarbonate meets acid, a weak acid will be form, and thus will form carbon dioxide and water, which will increase the salivary volume. This results is in accordance with Peterson ${ }^{12}$, Symonds ${ }^{16}$, Johnson and Chalmers ${ }^{17}$ which stated that rinsing with baking soda solution will increase the salivary volume, moist and lubricate the mouth, and reduce the symptoms of dry mouth caused by a decrease in saliva secretion.

After rinsing with baking soda solution the effect was the increase of saliva flow rate $(\mathrm{ml} /$ minutes) on menopause women by $0.086 \mathrm{ml} /$ minutes. 


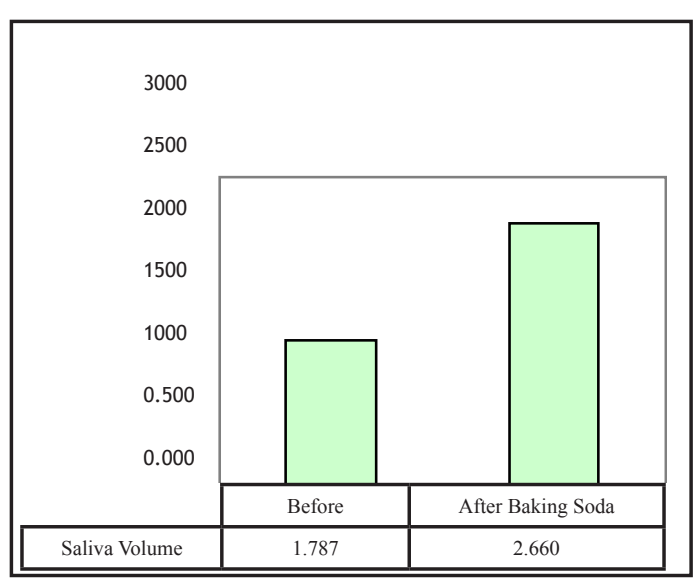

Figure 1. Saliva Volume differences $(\mathrm{ml})$ before and after rinsing with baking soda on Menopause women

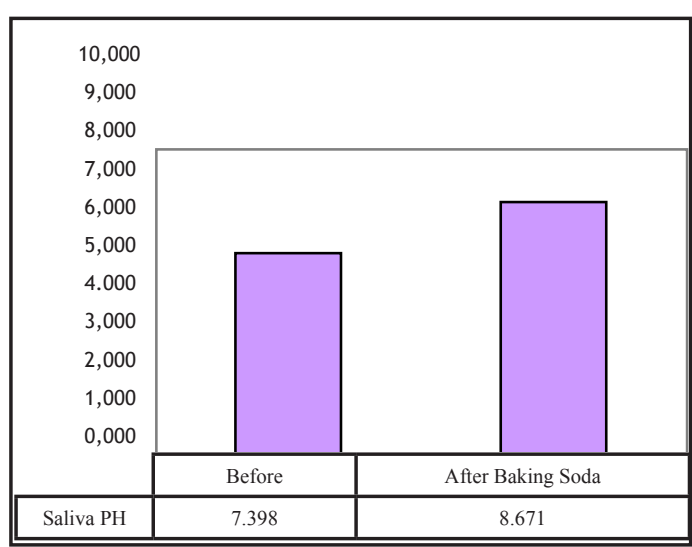

Figure 3. Saliva PH differences $(\mathrm{ml})$ before and after rinsing with baking soda on Menopause women

It means there was a difference between the saliva flow rate $(\mathrm{ml} /$ minute) before and after rinsing with baking soda solution. This is an accordance with the Rensburg ${ }^{18}$ who stated that the bicarbonate will increase the saliva flow rate and its ability to react toward acid. The acidic taste of baking soda solution will stimulate the parasympathetic nerve from nucleus salivatory superior and inferior on the brain stem. This nucleus will be excitated by tactile responses and taste from the tongue and other areas of oral cavity and pharynx, so to increase the saliva volume. ${ }^{6,9,18}$

Rinsing with baking soda solution gave rise to salivary $\mathrm{pH}$ on menopause women by 1.273 . It means that there was a difference on salivary $\mathrm{pH}$ before and after rinsing with baking soda solution. This is in accordance with Heydorn ${ }^{6}$, who stated that baking soda is an alkali agent and Bradley ${ }^{19}$, who stated that the salivary $\mathrm{pH}$ could increase to 8 if there was an increase in bicarbonate ions.

Rinsing with baking soda solution gave

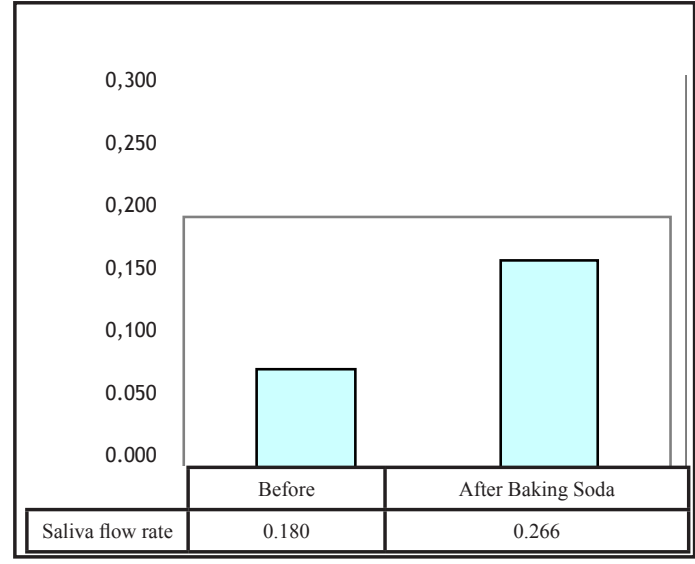

Figure 2. Saliva flow rate differences before and after rinsing with baking soda on Menopause women

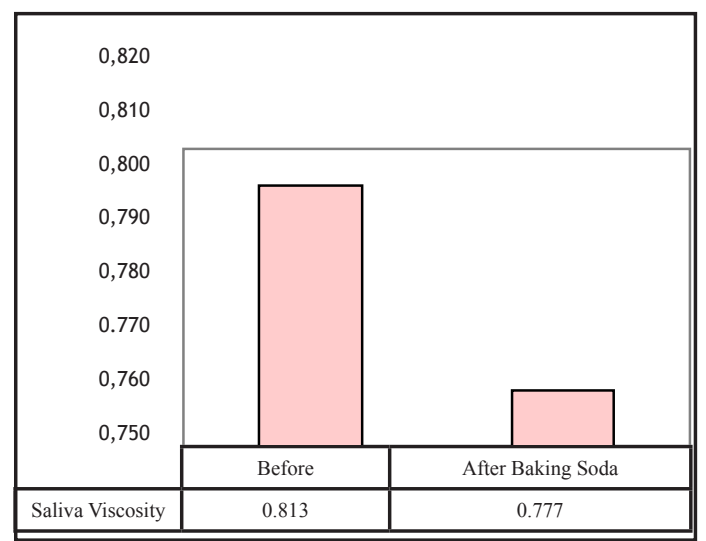

Figure 4. Saliva viscosity before and after rinsing with baking soda on Menopause women

an effect of decreasing the saliva viscosity on menopause women by 0.037 . There was a significant difference on saliva viscosity before and after rinsing with baking soda solution. This is in accordance with Turner and coworkers ${ }^{20}$, who stated that baking soda solution, can decrease the mucosa viscosity, thus it could be used as a rinsing agent on nostril and throat. The t-student test showed a significant difference between saliva secretion before and after rinsing with baking soda $(a=0.05)$. Statistically, it meant a significant difference on saliva secretion before and after rinsing with baking soda solution.

The baking soda dose as a mouth rinse in this research is the recommended dose for patients with saliva secretion disorder. ${ }^{12,21}$ For other disorders, this dose can be too toxic or too small to be effective against the stimulation of saliva secretion changes. The systemic effect that may occur when baking soda solution is accidentally swallowed is stomach inflating and flatus by the 
formation of $\mathrm{CO}_{2}$ gas. On this situations, patients are advised to drink a lot of water, then weak vinegar acid, orange juice (diluted with water by $1: 4)$, or a lot of milk. ${ }^{15}$

\section{CONCLUSION}

The estrogen decrease on menopause women can cause dryness in the oral cavity, and this increase the risk of caries on teeth surfaces and inflammation on oral mucosa. The taste substances which stimulate the secretion and parasympathicomimetica can reduce further damage. The safe, cheap and practical mouth rinse which can be used is baking soda solution. From this research, it is showed that rinsing with baking soda solution on menopause women can increase saliva secretion. There is a significant difference between saliva secretion before and after rinsing with baking soda solution.

\section{SUGGESTIONS}

There is a need for further experiments regarding the side effects, toxicity, and also the effective amount of baking soda solution rinse preparation. According to the existing research and scientific evidence, for the time being the use of baking soda solution can be recommended as a mouth rinse on menopause women.

\section{REFERENCES}

1. Roukema PA. Ludah. In: Howink, et al. Ilmu kedokteran gigi pencegahan. Yogyakarta: Gadjah Mada Univ Press; 1993. p.106-24.

2. Edman CD. Klimaterium dan menopause. In: Duenhoelter JH. Ginekologi Greenhill.10 ${ }^{\text {th }}$ ed. Jakarta: EGC; 1988. p. 303-7.

3. Hikmah N, Djamhari M, Hadi P. Perbedaan flow saliva antara wanita pre menopause dan pasca menopause. Maj Ked Gigi 2003; 36(2):74-6.

4. Glickman I, Jerome BS. Periodontal disease: clinical, radiographic and histopathologic features. Philadelphia: WB. Saunders Co;1974

5. Amerongen AVN. Speeksel en speekselklieren: betekenis voor mondgezondheid (ludah dan kelenjar ludah, arti bagi kesehatan gigi).
Yogyakarta: Gajah Mada University Press; 1992. p. 1-261.

6. Heydorn JD, Kathy L, Marjorie KS. Drug information. American Hospital Formulary Service; 1991. p. 1209-12.

7. McCombs G. Effects of a chewable sodium bicarbonate oral composition of plaque and gingivitis. J Cont Dent Pract 2001;7(4):1-8.

8. Featherstone J, Steven MA, Maxwell HA, et al. Consensus statement: Caries management by risk assessment. J Cal Dent Assoc 2003; 31(2):129-33.

9. Guyton AC. Buku ajar fisiologi kedokteran. $9^{\text {th }}$ ed. Jakarta: EGC; 1997. p. 1016-7.

10. Burket LW. Oral medicine diagnosis and treatment. $\quad 9^{\text {th }}$ ed. Philadelphia: J.B. Lippinciation; 1997. p. 1-7.

11. Singarimbun M, Efendi S. Metode penelitian survei. Yogyakarta: LP3ES. 1987.

12. Peterson D. Family gentle dental care: mouth rinse. 1998 [cited 2006 Sep]. Avalaible from: http://www.mouthrinse.com.

13. Navazesh M. Method for collecting saliva. Annuals of The New York Academy of Sciences. 1994;694:73-7.

14. Roth GI, Calmes R. Oral biology. St. Louis: CV. Mosby Co; 1981:196-231.

15. Mutschler E. Dinamika obat. Bandung: ITB;1991. p. 745-6.

16. Symonds N. Dealing with mouth problems. 1998. Avalaible from: http://www.Learning Place online.com.

17. Johnson V, Chalmers J. Oral hygiene care for functionally dependent and cognitively impaired older adults. 2002. Avalaible from: http://www.guidelin.gov/about/inclusion. aspx.

18. Rensburg BGJV. Oral biology. Chicago: Quintessence Publishing Co. Inc.; 1995. p. 459-78.

19. Bradley RM. Essential of oral physiology. St. Louis: The CV. Mosby Co; 1995. p. 184.

20. Turner PJ, Balmford E. Becket AH, et al. Drugs and pharmaceutical adjuvant. London: The Pharmaceutical Press; 1974. p. 444

21. Hicks J. Mouth sores: causes, treatments and potential new treatments. [cited 2003]. Avalaible from: http://www.biotenekits.com. 